\title{
Assessment of risk factors for hypertension and obesity among adolescents
}

\author{
*Sunita Arora ${ }^{1}$, Shifali Gupta ${ }^{2}$, Pushpjeet Singh ${ }^{3}$ \\ Sri Lanka Journal of Child Health, 2017; 46: 48-54
}

\begin{abstract}
Introduction: The rising trend of noncommunicable diseases (NCDs) globally and their associated mortality and morbidity, with a shift to the younger population is a matter of concern.
\end{abstract}

Objective: To study the risk factors for hypertension and obesity among adolescents

Design and setting: Hospital based cross sectional study in the paediatric outpatient department (OPD) of a tertiary care hospital.

Subjects: Adolescents in the age group 10-18 years presenting to the paediatric OPD from $13^{\text {th }}$ January 2013 to $14^{\text {th }}$ December 2014.

Results: There were 218 such adolescents of whom $51 \%$ were female. Of the $218,37 \%$ had a family history $(\mathrm{F} / \mathrm{H})$ of hypertension, $27 \%$ a $\mathrm{F} / \mathrm{H}$ of diabetes mellitus, $17 \%$ a $\mathrm{F} / \mathrm{H}$ of obesity, $17 \%$ a $\mathrm{F} / \mathrm{H}$ of cardiovascular diseases and $4 \%$ a $\mathrm{F} / \mathrm{H}$ of cerebrovascular accidents. There was a history of passive smoking in $41 \%$, consumption of aerated drinks in $73 \%$ and fast food consumption in $92 \%$. Tobacco consumption was recorded in $1.8 \%$ and alcohol consumption in $2.9 \%$. Fifteen $(6.9 \%)$ subjects were found to be overweight and one $(0.4 \%)$ subject was obese. Twenty two $(10 \%)$ had systolic hypertension and $23(10.5 \%)$ diastolic hypertension. BMI had a significant correlation with systolic and diastolic hypertension.

Conclusions: Fast food consumption was present in $92 \%$ of adolescents and physical activity with duration less than 30 minutes in $44.5 \%$ of adolescents in this study. BMI was significantly associated with both systolic and diastolic hypertension in this study.

DOI: http://dx.doi.org/10.4038/sljch.v46i1.8120

${ }^{1}$ Sri Guru Ramdas Institute of Medical Sciences $\&$ Research (SGRDIMSR), Amritsar, India

*Correspondence: dr.sunita1@yahoo.com

(Received on 10 May 2016: Accepted after revision on 17 June 2016)

The authors declare that there are no conflicts of interest

Personal funding was used in formulating the article.

Open Access Article published under the Creative

Commons Attribution CC-BY (cc) (i) License.
(Key words: Adolescents, hypertension, obesity, diabetes, non-communicable diseases)

\section{Introduction}

Non-communicable diseases (NCDs) such as diabetes, hypertension, cardiovascular diseases, stroke, obesity, dyslipidaemia and malignancy account for $60 \%$ of deaths and $47 \%$ of the global burden of disease ${ }^{1}$. Prevalence of childhood hypertension is noted to be $5-10 \%$ in developing countries and $1-2 \%$ in developed countries ${ }^{2}$. In India, adolescents account for almost $20 \%$ of its population $^{3}$. Risk factors like fast food consumption, low physical activity, high level of experimentation with alcohol and smoking have led to a high prevalence of obesity and hypertension in adolescents ${ }^{4}$. All these risk factors are preventable and modifiable.

Moderate to vigorous physical activity like brisk walking, dancing, swimming or cycling, if done regularly ( $\geq 3$ times per week) decreases risk of NCDs by weight loss, reduction of visceral fat with lowering of blood pressure and improved glucose control by increased insulin sensitivity ${ }^{5}$. Tobacco use among adolescents can be initiated by its use by elders in the family, peer influence, experimentation, underlying emotional and psychological factors, risk taking behaviour and aggressive marketing stratergies ${ }^{6}$. Family history of hypertension is an important non modifiable risk factor for hypertension ${ }^{7}$. Having a parent with noninsulin dependent diabetes mellitus (NIDDM) increases two to fourfold an offspring's chance of developing this condition ${ }^{8}$.

\section{Objectives}

To study the risk factors for hypertension and obesity among adolescents.

\section{Method}

This study was conducted in the paediatric outpatient department (OPD) of Sri Guru Ramdas Institute of Medical Sciences \& Research (SGRDIMSR), Amritsar, a tertiary care centre in India, from $13^{\text {th }}$ January 2013 to $14^{\text {th }}$ December 2014. Adolescents aged 10-18 years attending paediatric OPD during the study period, after taking informed consent from their parents or guardian, were enrolled. Study was approved by the Ethics Committee of SGRDIMSR. Children suffering from chronic cardiovascular, respiratory, endocrine, musculoskeletal and renal disorders, obesity due to hereditary, genetic and metabolic 
disorders and children on medication known to affect blood pressure were excluded from the study.

It was a cross sectional hospital based study. A pretested structured, close ended questionnaire was used for data collection after explaining in vernacular language. Questionnaire sought information regarding demographic details, dietary practices, physical activity, time spent on television, video games, computer, history of smoking, family history of hypertension, diabetes, obesity, stroke or malignancy in parents. Weight was recorded with minimal permissible clothes with accurate standard electronic weighing scale with a precision of \pm 10 grams. Height was measured with stadiometer to the nearest $0.1 \mathrm{~cm}$. BMI was calculated using the formula weight $(\mathrm{kg})$ /height $\left(\mathrm{m}^{2}\right)$. According to CDC 2000, BMI for gender and age $>85^{\text {th }}$ percentile was considered overweight and BMI $>95^{\text {th }}$ percentile was considered obese ${ }^{9}$. Blood pressure was recorded in the right arm in the sitting position with appropriate cuff size by auscultatory method with sphygmomanometer. Sufficient time was given to allay anxiety and fear. First and fifth phases of Korotkoff sounds was taken as systolic and diastolic blood pressure. Two more measurements were taken at 15 and 30 minutes and mean of three readings was taken as final observation. BP was classified as normal, prehypertension, stage 1 and stage 2 hypertension with respect to age, sex and height percentile ${ }^{10}$.

Observations were expressed as frequency distribution. Statistical significance was evaluated using Pearson's Chi-square and, Student's t-test. Comparison of mean BMI across stages of SBP and DBP was carried out by using one way ANOVA. All analysis were performed using SPSS 18.0 (SPSS Inc) software and statistical significance was evaluated at $5 \%$ value.

\section{Results}

Two hundred and eighteen adolescents in the age group 10-18 years were enrolled for the study. Of them $107(49 \%)$ were male and $111(51 \%)$ were female. One hundred and fifty three $(70 \%)$ were in the 10-14 year age group. Males outnumbered females in 10-14 year age category whereas females outnumbered males in the over 14 year age category. Majority of participants were of normal stature but $37 \%$ had short stature. Whilst $78 \%$ of participants had a normal BMI, around $15 \%$ were underweight and $07 \%$ were overweight. Distribution of age, stature and BMI according to gender is shown in Table 1. Distribution of participants according to risk factors and risk score within family is shown in Table 2 .

Table 1: Distribution of age, stature and BMI according to gender

\begin{tabular}{|c|c|c|c|}
\hline & $\begin{array}{l}\text { Male }(n=107) \\
\text { Number (\%) }\end{array}$ & $\begin{array}{c}\text { Female }(n=111) \\
\text { Number }(\%)\end{array}$ & $\begin{array}{l}\text { Total }(n=218) \\
\text { Number }(\%)\end{array}$ \\
\hline $\begin{array}{l}\text { Age (years) } \\
10-14 \\
>14\end{array}$ & $\begin{array}{l}93(86.9) \\
14(13.1)\end{array}$ & $\begin{array}{l}60(54.1) \\
51(45.9)\end{array}$ & $\begin{array}{c}153(70.1) \\
65(29.9)\end{array}$ \\
\hline $\begin{array}{l}\text { Stature }(\mathrm{cm}) \\
<5^{\text {th }} \text { centile } \\
5^{\text {th }}-95^{\text {th }} \text { centile } \\
>95^{\text {th }} \text { centile }\end{array}$ & $\begin{array}{c}33(30.8) \\
74(69.2) \\
0(0) \\
\end{array}$ & $\begin{array}{l}48(43.2) \\
62(55.9) \\
01(0.9)\end{array}$ & $\begin{array}{c}81(37.2) \\
136(62.3) \\
01(0.5)\end{array}$ \\
\hline $\begin{array}{l}\text { Body mass index }(\text { BMI }) \\
\text { Underweight }\left(<5^{\text {th }} \text { centile }\right) \\
\text { Normal }\left(5^{\text {th }}-84^{\text {th }} \text { centile }\right) \\
\text { Overweight }\left(85^{\text {th }}-95^{\text {th }} \text { centile }\right) \\
\text { Obese }\left(>95^{\text {th }} \text { centile }\right)\end{array}$ & $\begin{array}{c}19(17.8) \\
80(74.8) \\
08(07.4) \\
0(0)\end{array}$ & $\begin{array}{l}13(11.7) \\
90(81.1) \\
07(06.3) \\
01(0.9)\end{array}$ & $\begin{array}{c}32(14.7) \\
170(78.0) \\
15(06.9) \\
01(0.4)\end{array}$ \\
\hline
\end{tabular}

Table 2: Distribution according to risk factors and risk score within family

\begin{tabular}{|l|c|c|c|}
\hline \multicolumn{1}{|c|}{ Risk factors } & Number (\%) & Risk score & Number (\%) \\
\hline Hypertension & $81(37.2)$ & 0 & $46(21.1)$ \\
\hline Cardiovascular disease & $38(17.4)$ & 1 & $76(34.9)$ \\
\hline Diabetes mellitus & $60(27.5)$ & 2 & $53(24.3)$ \\
\hline Cerebrovascular accident & $09(04.1)$ & 3 & $35(16.0)$ \\
\hline Obesity & $37(17.0)$ & 4 & $07(03.2)$ \\
\hline Passive smoking & $90(41.3)$ & 5 & $01(0.5)$ \\
\hline
\end{tabular}

Family history of passive smoking, hypertension and diabetes mellitus were the 3 most common risk factors (Table 1). Forty six (21\%) had no family history of risk factors and a risk score of zero.
Whilst $76(35 \%)$ of the participants had a risk score of one, $96(44 \%)$ had risk scores ranging from 2 to 5. Distribution of participants according to physical activity and dietary habits is shown in Table 3. 
Table 3: Distribution of participants according to physical activity and dietary habits

\begin{tabular}{|c|c|c|c|}
\hline & $\begin{array}{c}\text { Male }(n=107) \\
\text { Number (\%) }\end{array}$ & $\begin{array}{c}\text { Female }(n=111) \\
\text { Number (\%) }\end{array}$ & $\begin{array}{c}\text { Total }(\mathrm{n}=218) \\
\text { Number (\%) }\end{array}$ \\
\hline Physical activity duration: $<30$ mins & $48(44.9)$ & $49(44.1)$ & $97(44.5)$ \\
30 mins or $>$ & $59(55.1)$ & $62(55.9)$ & $121(55.5)$ \\
\hline Type of activity: Indoor Outdoor & - & - & $42(19.3)$ \\
Yes & - & - & $176(80.7)$ \\
\hline Fast food consumption: No & $13(72.2)$ & $05(27.8)$ & $18(08.3)$ \\
Frequency: 3-6 days/week & $94(47.0)$ & $106(53.0)$ & $200(91.7)$ \\
Daily & & & $115(57.5)$ \\
Type of diet: Vegetarian & - & - & $85(42.5)$ \\
Non vegetarian & - & - & $100(45.9)$ \\
Aerated drinks: No & - & - & $118(54.1)$ \\
Yes & & & $160(73.4)$ \\
Frequency: 0-2 days/week & & & $81(50.6)$ \\
3-6 days/week & & & $76(47.5)$ \\
Daily & & & $03(01.9)$ \\
\hline
\end{tabular}

There was no gender difference in the duration of physical activity. Two hundred $200(92 \%)$ children consumed fast food, $85(42.5 \%)$ consuming them daily. History of aerated drink consumption was present in $160(73 \%)$ subjects of whom $76(47.5 \%)$ consumed them 3-6 times per week. BMI and its relation to various factors is shown in Table 4.

Table 4: BMI and its relationship to various factors

\begin{tabular}{|c|c|c|c|}
\hline & \multicolumn{2}{|c|}{ BMI } & \multirow[t]{2}{*}{ p value } \\
\hline & $<85^{\text {th }}$ centile & $\geq 85^{\text {th }}$ centile & \\
\hline Family history of obesity: Absent & 167 & 14 & \\
\hline Present & 35 & 02 & 0.8814 \\
\hline Duration of activity min / day & $54.38 \pm 15.37$ & $43.94 \pm 18.60$ & $0.01889(<0.05)$ \\
\hline Meal skipped: Absent & 104 & 11 & \\
\hline Present & 98 & 05 & 0.284 \\
\hline Fast food consumption: Yes & \multicolumn{2}{|c|}{$17.90 \pm 2.552($ mean $\pm \mathrm{SD})$} & \\
\hline No & \multicolumn{2}{|c|}{$17.76 \pm 2.999($ mean $\pm \mathrm{SD})$} & 0.0819 \\
\hline
\end{tabular}

Family history of obesity and skipping of meals were not significantly associated with BMI. Mean duration of physical activity was significantly higher in those with lower BMI $(p<0.05)$.
Consumption of fast food did not have a significant correlation with BMI. Distribution of participants according to systolic and diastolic blood pressure is shown in Table 5.

Table 5: Distribution of participants according to systolic and diastolic blood pressure

\begin{tabular}{|c|c|c|c|c|}
\hline Blood pressure centile & $\begin{array}{l}\text { Male }(n=107) \\
\text { Number }(\%)\end{array}$ & $\begin{array}{c}\text { Female }(\mathrm{n}=111) \\
\text { Number }(\%)\end{array}$ & $\begin{array}{c}\text { Total } \\
\text { Number }(\%)\end{array}$ & P value \\
\hline $\begin{array}{l}\text { Systolic blood pressure }(\mathrm{mm} \mathrm{Hg}) \\
<90^{\text {th }} \text { (normal) } \\
90^{\text {th }}-95^{\text {th }} \text { (Prehypertension) } \\
96^{\text {th }}-99^{\text {th }} \text { (Stage } 1 \text { hypertension) } \\
>99^{\text {th }} \text { (Stage } 2 \text { hypertension) }\end{array}$ & $\begin{array}{c}96(89.7) \\
07(06.5) \\
03(02.8) \\
01(0.9)\end{array}$ & $\begin{array}{l}90(81.1) \\
03(02.7) \\
09(08.1) \\
09(08.1)\end{array}$ & $\begin{array}{c}186(85.3) \\
10(04.5) \\
12(05.5) \\
10(04.5)\end{array}$ & $0.011(<0.05)$ \\
\hline $\begin{array}{l}\text { Diastolic blood pressure }(\mathrm{mm} \mathrm{Hg}) \\
<90^{\text {th }} \text { (normal) } \\
90^{\text {th }}-95^{\text {th }}(\text { Prehypertension) } \\
96^{\text {th }}-99^{\text {th }} \text { (Stage } 1 \text { hypertension) } \\
>99^{\text {th }}(\text { Stage } 2 \text { hypertension) }\end{array}$ & $\begin{array}{l}88(82.2) \\
07(06.5) \\
09(08.4) \\
03(02.8)\end{array}$ & $\begin{array}{l}90(81.1) \\
10(09.0) \\
07(06.3) \\
04(03.6)\end{array}$ & $\begin{array}{c}178(81.6) \\
17(07.8) \\
16(07.3) \\
07(03.2)\end{array}$ & $0.832(>0.05)$ \\
\hline
\end{tabular}

Majority of the subjects had normal systolic and diastolic blood pressures. Females outnumbered males in stage 1 and 2 systolic hypertension. The distribution of participants in relation to systolic BP stages between two genders was statistically significant. Difference of diastolic BP between males and females was not statistically significant. The association of systolic/diastolic BP with BMI, risk score and physical activity is shown in Table 6. 
Table 6: Association of SBP/DBP with BMI, risk score and physical activity

\begin{tabular}{|c|c|c|c|c|c|}
\hline & Normal & Pre-hypertension & Stage 1 & Stage 2 & p value \\
\hline $\begin{array}{l}B M I\left(\mathrm{~kg} / \mathrm{m}^{2}\right) \\
\text { mean } \pm \mathrm{SD}(\mathrm{SBP}) \\
\text { mean } \pm \mathrm{SD}(\mathrm{DBP})\end{array}$ & $\begin{array}{l}17.69 \pm 2.277 \\
17.64 \pm 2.362\end{array}$ & $\begin{aligned} 17.45 & \pm 3.59618 .39 \\
& \pm 3.608\end{aligned}$ & $\begin{array}{l}19.05 \pm 3.778 \\
18.72 \pm 2.366\end{array}$ & $\begin{array}{l}20.72 \pm 3.510 \\
21.62 \pm 3.558\end{array}$ & $\begin{array}{l}0.001 \\
0.002\end{array}$ \\
\hline $\begin{array}{l}\text { Risk score } \\
<2 \text { (SBP) } \\
3-4(\mathrm{SBP}) \\
>5(\mathrm{SBP}) \\
<2(\mathrm{DBP}) \\
3-4(\mathrm{DBP}) \\
>5(\mathrm{DBP})\end{array}$ & $\begin{array}{c}148 \\
37 \\
01 \\
138 \\
39 \\
01 \\
\end{array}$ & $\begin{array}{c}07 \\
03 \\
0 \\
15 \\
02 \\
0\end{array}$ & $\begin{array}{c}11 \\
01 \\
0 \\
15 \\
01 \\
0\end{array}$ & $\begin{array}{c}09 \\
01 \\
0 \\
07 \\
0 \\
0\end{array}$ & 0.691 \\
\hline $\begin{array}{l}\text { Physical activity } \\
\text { Indoor (SBP) } \\
\text { Outdoor (SBP) } \\
\text { Indoor (DBP) } \\
\text { Outdoor (DBP) }\end{array}$ & $\begin{array}{c}39 \\
147 \\
36 \\
142 \\
\end{array}$ & $\begin{array}{c}02 \\
08 \\
0 \\
17\end{array}$ & $\begin{array}{c}0 \\
12 \\
03 \\
13\end{array}$ & $\begin{array}{l}01 \\
09 \\
03 \\
04\end{array}$ & $\begin{array}{l}0.288 \\
0.083\end{array}$ \\
\hline
\end{tabular}

SBP: Systolic blood pressure DBP: Diastolic blood pressure BMI: Body mass index SD: Standard deviation

Maximum mean BMI (20.72 \pm 3.510$)$ was observed for stage 2 systolic hypertension and minimum mean BMI $(17.45 \pm 3.596)$ was observed for pre-hypertension. Using one way ANOVA method, relation between BMI and systolic BP categories was found to be significant $(\mathrm{p}=0.001)$. Similarly maximum mean BMI $(21.62 \pm 3.558)$ was observed in stage 2 diastolic hypertension and minimum mean BMI $(17.64 \pm 2.362)$ was observed in subjects with normal DBP. Relation between BMI and DBP stages was significant $(p=0.002)$.
Systolic and diastolic BP did not show a significant association with risk score categories using Pearson's Chi square test resulting in $\mathrm{p}$ values of 0.436 and 0.691 respectively. Systolic and diastolic BP did not show a significant association with type of physical activity (indoor or outdoor) resulting in $\mathrm{p}$ values of 0.288 and 0.083 respectively. Table 7 shows SBP/DBP categories according to BMI, diet and family history of hypertension.

Table 7: SBP/DBP categories according to BMI, diet and family history of hypertension

\begin{tabular}{|l|c|c|c|c|c|}
\hline & Normal & Pre-hypertension & Stage 1 HT & Stage 2 HT & p value \\
\hline BMI & & & & & \\
$\leq 85^{\text {th }}$ centile (SBP) & 178 & 08 & 10 & 06 & $<0.0001$ \\
$>85^{\text {th }}$ centile (SBP) & 08 & 02 & 02 & 04 & \\
$\leq 85^{\text {th }}$ centile (DBP) & 170 & 15 & 14 & 03 & $<0.0001$ \\
$>85^{\text {th }}$ centile (DBP) & 08 & 02 & 02 & 04 & \\
\hline Diet & & & 05 & 01 & 0.0364 \\
Vegetarian (SBP) & 90 & 04 & 07 & 09 & \\
Non-Vegetarian (SBP) & 96 & 06 & 10 & 01 & 0.3172 \\
Vegetarian (DBP) & 85 & 04 & 06 & 06 & \\
Non-Vegetarian (DBP) & 93 & 13 & 10 & 09 & 0.8091 \\
\hline Family history of HT & 118 & 05 & 02 & 06 & \\
Yes (SBP) & 68 & 05 & 13 & 04 & 0.8956 \\
No (SBP) & 111 & 09 & 03 & 03 & \\
Yes (DBP) & 67 & 08 & & & \\
No (DBP) & & & & & \\
\hline
\end{tabular}

Obtained using Chi square test

SBP: Systolic blood pressure DBP: Diastolic blood pressure BMI: Body mass index HT: Hypertension

BMI centile showed a highly significant association with various stages of SBP and DBP. Association of SBP with type of diet was significant whereas the association of DBP with type of diet was not significant. No statistically significant association was observed between family history of hypertension and SBP/DBP.

\section{Discussion}

Increasing prevalence of NCDs due to rapid urbanisation and globalisation in India is a cause of great concern. A rising trend is being observed in adolescents with its serious consequences in future adulthood. It is pertinent to investigate preventable risk factors in order to implement integrated preventive strategies. 
Gender distribution of 218 adolescents enrolled in the present study was almost equal and $153(70 \%)$ were in 10-14 year age group. Similar gender distribution was observed by SV Mane et al in 2012 ${ }^{11}$. AK Singh et al and Ali Khuwaja et al observed slight preponderance of boys ${ }^{4,12}$. One hundred and twenty one subjects fulfilled the requirement of physical activity of more than 30 minutes as per WHO recommendations and there was no significant difference in males and females. Shah et al in 2005 in a study done across 81 regions of India showed inactivity levels as $12.6 \%$ in males and $18.9 \%$ in females ${ }^{13}$.

SV Mane et al in 2012 observed a $\mathrm{F} / \mathrm{H}$ of diabetes in $30 \%$ adolescents, a $\mathrm{F} / \mathrm{H}$ of hypertension in $26.5 \%$ and a $\mathrm{F} / \mathrm{H}$ of heart diseases and obesity in $20.5 \%$ each $^{11}$. AK Singh et al in 2006 reported a $\mathrm{F} / \mathrm{H}$ of hypertension in $50 \%$ each of boys and girls and a $\mathrm{F} / \mathrm{H}$ of obesity in $23 \%$ of boys and $30 \%$ of girls ${ }^{4}$. In the present study, $37 \%$ had a family history $(\mathrm{F} / \mathrm{H})$ of hypertension, $27 \%$ had a $\mathrm{F} / \mathrm{H}$ of diabetes mellitus, $17 \%$ a $\mathrm{F} / \mathrm{H}$ of obesity, $17 \%$ a $\mathrm{F} / \mathrm{H}$ of cardiovascular disease and $4 \%$ a $\mathrm{F} / \mathrm{H}$ of cerebrovascular accidents. AK Singh et al in 2006 and Khan $\mathrm{H}$ et al in 2010 reported a positive correlation of hypertension in those adolescents who had positive $\mathrm{F} / \mathrm{H}$ of hypertension ${ }^{4,14}$. No significant association was found between a $\mathrm{F} / \mathrm{H}$ of hypertension and BP profile of adolescents in the present study.

Joshi $\mathrm{H}$ et al 2014 reported that $23.5 \%$ adolescents consumed junk food twice or more per week ${ }^{15}$. In the study by Rani et al 2013, 85\% students reported eating fast food with $22 \%$ eating it for more than three days a week ${ }^{16}$. In our study $200(91.7 \%)$ adolescents consumed fast food with a frequency of 3-6 times per week in 57.5\% and daily consumption in $42.5 \%$. A matter of grave concern was that fast food consumption was in addition to their regular meals in 145 out of 218 adolescents in the present study. In the present study, 106 (53\%) girls had a history of fast food consumption compared with 94 (47\%) boys. Ranjit et al 2010 and Vereecken et al 2005 made observations to the contrary ${ }^{17,18}$. Smoking prevalence has varied from $8.8 \%$ to $13.1 \%$ in different studies ${ }^{19}$. Tobacco consumption was low $(1.8 \%)$ in the present study. Alcohol consumption was recorded in $2.9 \%$ in our study. A higher prevalence $(7.4 \%)$ was reported by Tsering et al in $2010^{20}$.

Overweight and obesity was found in $3.1 \%$ and $2.1 \%$ respectively by Bharati et al $2008^{21}$. Out of 218 adolescents, 15 subjects $(6.88 \%)$ were found to be overweight with equal distribution among both genders. Only 1 subject $(0.4 \%)$ was obese. Chandla et al in 2009 revealed similar prevalence as was found in present study ${ }^{22}$. Laxmaiah A et al 2007 reported higher prevalence in females $(8.2 \%)$ as compared to males $(6.1 \%)^{23}$. A higher prevalence of overweight and obesity was reported by $\mathrm{AK}$ Singh et al 2006 (18.6\% boys and $16.5 \%$ girls $)^{4}$. Lack of correlation of fast food consumption and obesity in present study was probably because duration of physical activity as recommended by WHO was fulfilled by half of the study population.

Out of 218 subjects, 22 (10\%) had systolic hypertension. Females outnumbered males (18 vs 4) and the difference was statistically significant. Diastolic hypertension was detected in 23 subjects $(10.5 \%)$ but gender difference was not significant. Prevalence of hypertension of $8.5 \%$ has been reported by Demirci $\mathrm{H}$ et al $2013^{24}, 5.4 \%$ by Patel et al $2014^{25}, 9.78 \%$ by Khan $\mathrm{M}$ et al $2010^{13}$ and $10.91 \%$ by Borade et al $2011^{26}$. Durrani et al 2011 found lower prevalence of hypertension in boys $(9.36 \%)$ as compared to girls $(9.4 \%)^{27}$. Lower prevalence in females $(11.76 \%)$ has been reported as compared to boys $(13.79 \%)$ by Lone et al $2015^{28}$. Association between systolic and diastolic hypertension and family history of hypertension was not statistically significant in present study. However AK Singh et al 2006 highlighted such association in their study ${ }^{4}$. Family history of obesity which was present in $37 \%$ of subjects was not statistically significant in relation to both systolic and diastolic hypertension in present study. BMI had a statistically significant correlation with SBP/DBP. Systolic Prehypertension was found in $10(4.5 \%)$ and diastolic prehypertension was found in $17(7.75 \%)$ subjects. Similar observations were made by Patel et al in $2014^{25}$. Higher prevalence of $15.7 \%$ and $24.5 \%$ was reported by Mc Niece KL et al 2007 and Madhavikutty Amma GD et al $2015^{29,30}$. AK Singh et al 2006 found more prevalence in males $(11.82 \%)$ than females $(3 \%)$ and overall prevalence of systolic hypertension was lower $(7.84 \%)^{4}$. High prevalence of isolated systolic hypertension (37.4\%) was reported by Khan M I et al $2010^{14}$.

\section{Conclusions}

- Fast food consumption was present in $92 \%$ of adolescents in this study.

- Physical activity with duration less than 30 minutes was present in $44.5 \%$ of adolescents in this study.

- Systolic and diastolic hypertension were detected in $10 \%$ and $10.5 \%$ subjects respectively.

- BMI was significantly associated with both systolic and diastolic hypertension in this study. 


\section{References}

1. Divakaran B, Muttapillymyalil J, Sreedharan J, Shalini K. Lifestyle risk factors of non-communicable diseases: awareness among school children. Indian Journal of Cancer 2010; 47 (Suppl 1):9-13. https://doi.org/10.4103/0019-509X.63864 PMid: 20622407

2. Luma GB, Spiotta RT. Hypertension in children and adolescents. American Family Physician 2006; 73(9):1558-68. PMid: 16719248

3. The State of the World's Children 2011. Adolescence: The age of opportunity, New York: UNICEF.

http://www.unicef.org/sowc2011/index.php

4. Singh AK, Maheshwari A, Sharma A, Anand K. Lifestyle associated risk factors in adolescents. Indian Journal of Pediatrics 2006; 73(10):901-6. https://doi.org/10.1007/BF02859283 PMid: 17090902

5. Centres for Disease Control and prevention, National Centre for Chronic Disease Prevention and Health promotion, Division of Nutrition and Physical Activity. Physical activity for everyone: physical activity terms. Available from: http://www.cdc.gov/nccdphp/dnpa/physica 1/terms/index.htm

6. Kapoor SK, Anand K, Kumar G. Prevalence of tobacco use among school and college going adolescents of Haryana. Indian Journal of Pediatrics 1995; 62(4):461-6. https://doi.org/10.1007/BF02755068

PMid: 10829906

7. Barlassina C, Lanzani C, Manunta $\mathrm{P}$, Bianchi G. Genetics of essential hypertension: from families to genes. Journal of the American Society of Nephrology 2002; 13 Suppl 3:S155-64. https://doi.org/10.1097/01.ASN.00000325 24.13069.88

PMid: 12466306

8. Pierce M, Keen H, Bradley C. Risk of diabetes in offspring of parents with non insulin dependent diabetes. Diabetic Medicine 1995; 12(1):6-13. https://doi.org/10.1111/j.14645491.1995.t b02054.x

PMid: 7712706
9. Kuczmarski RJ, Ogden CL, GrummerStrawn LM, Flegal KM, Guo SS, Wei R et al. CDC growth charts: United States. Advance Data 2000; (314):1-27.

PMid: 11183293

10. National High Blood Pressure Working Programme. Working group on high blood pressure in children and adolescents: The fourth report on the diagnosis, evaluation and treatment of high blood pressure in children and adolescents. Pediatrics 2004; 114(2 Suppl. $4^{\text {th }}$ Report): 555-76.

11. Mane SV, Agarkhedkar SR, Karwa DS, Pande V, Singhania SS, Karambelkar GR. Study of risk factors for lifestyle diseases among adolescents in Western India. Int $J$ Pharm Biomed Sci. 2012; 3(4):224-8.

12. Khuwaja A, Khawaja S, Motwani K, Khoja A, Azam I, Fatmi Z, Ali B, Kadir M et al. Preventable lifestyle factors for non communicable diseases in Pakistan Adolescents Schools Study. Journal of Preventive Medicine and Public Health 2011; 44(5):210-7. https://doi.org/10.3961/jpmph.2011.44.5.210 PMid: 22020186 PMCid: PMC3249258

13. Shah B, Anand K, Joshi P, Mahanta J, Mohan V, Thankappan K et al. Report of the surveillance of risk factors of non communicable diseases (Steps 1 \& 2 ) from 5 centres in India-WHO IndiaICMR initiative, New Delhi. Available from:

http://www.whoindia.org/linkfiles/NCD_s urveillance_NCD_RF_surveillance_report .pdf.2004

14. Khan M et al. Risk factors and prevalence of hypertension in adolescent boys of Ahmedabad city. Journal of Clinical and Diagnostic Research 2010; 4:3348-54.

15. Joshi H, Jethva V, Patel N. Changing food pattern in adolescents and impact on health. International Journal of Medical Science and Public Health 2014; 3(12):1442-50.

https://doi.org/10.5455/ijmsph.2014.03092 0141

16. Rani MA, Sathiyasekaran BW. Behavioural determinants for obesity: A cross sectional study among urban adolescents in India. Journal of Preventive Medicine and Public Health 2013; 46(4): 192-200. 
https://doi.org/10.3961/jpmph.2013.46.4.192

PMid: 23946877 PMCid: PMC3740224

17. Ranjit N, Evans MH, Byrd-Williams C, Evans AE, Hoelscher DM. Dietery and activity correlates of sugar sweetened beverage consumption among adolescents. Pediatrics 2010; 126(4):754-61. https://doi.org/10.1542/peds.2010-1229 PMid: 20876172 PMCid: PMC3045775

18. Vereecken CA, Inchley J, Subramanian SV, Hublet A, Maes L. The relative influence of individual and contextual socio economic status on consumption of fruit and soft drinks among adolescents in Europe. European Journal of Public Health 2005; 15(3):224-32.

https://doi.org/10.1093/eurpub/cki005

PMid: 15905182

19. Narain R, Sardana S, Gupta S, Sehgal A. Age at initiation and prevalence of tobacco use among school children in Noida, India; A cross sectional questionnaire based survey. Indian Journal of Medical Research 2011; 133: 300-7.

PMid: 21441684 PMCid: PMC3103155

20. Tsering D, Pal R, Dasgupta A. Substance use among adolescent high school students in India: A survey of knowledge, attitude and opinion. Journal of Pharmacy and Bioallied Sciences 2010; 2(2):137-40. https://doi.org/10.4103/0975-7406.67005 PMid: 21814448 PMCid: PMC3147098

21. Bharati DR, Deshmukh PR, Garg BS. Correlates overweight and obesity among school going children of Wardha city. Central India. Indian Journal of Medical Research.2008; 127(6):539-43. PMid: 18765871

22. Chandla S, Grover K, Jain R. Childhood obesity: A growing concern. Social Welfare 2009; 55(10):27.

23. Laxmaiah A, Nagalla B, Vijayaraghavan K, Nair M. Factors affecting prevalence of overweight among 12 to 17 year old urban adolescents in Hyderabad, India. Obesity 2007; 15(6):1384-90.

https://doi.org/10.1038/oby.2007.165

PMid: 17557974
24. Demirci H, Nuhoglu C, Ursavas IS, Isildak S, Basaran EO. Kilic MY. Obesity and asymptomatic hypertension among children aged 6-13 years living in Bursa, Turkey. Family Practitioner 2013; 30(6): 629-33.

https://doi.org/10.1093/fampra/cmt048

PMid: 24068599

25. Patel U, Patel NP, Jain S, Ratre BK, Shrivastava $\mathrm{S}$ et al. High blood pressure in school going adolescents: prevalence and risk factors. Pediatric Review: International Journal of Pediatric Research 2014; 1(1). Available from: http://www.pediatricreview.in/

26. Borade A, Kadam GS, Bhide G, Dhongade R. Study of Blood pressure and blood sugar levels in adolescence and comparison with body mass index. Indian Journal of Medical Science 2011; 65(7): 297-310.

https://doi.org/10.4103/0019-5359.107391 PMid: 23422703

27. Durrani AM, Waseem F. Blood pressure distribution and its relation to anthropometric measurements among school children in Aligarh. Indian Journal of Public Health 2011; 55(2):121-4. https://doi.org/10.4103/0019-557X.85246 PMid: 21941047

28. Lone DK, Thakre SS, Borkar AM, Deshmukh NN, Thakre SB et al. Anthropometric correlates of blood pressure among school children in Nagpur city, central India: A cross sectional study. International Journal of Medicine and Public Health 2014; 4(14):436-40. https://doi.org/10.4103/2230-8598.144128

29. McNiece KL, Poffenbarger TS, Turner JL, Franco KD, Sorof JM, Portman RJ. Prevalence of hypertension and pre hypertension among adolescents. Journal of Pediatrics 2007; 150(6):640-4. https://doi.org/10.1016/j.jpeds.2007.01.052 PMid: 17517252

30. Madhavikutty Amma GD et al. Prevalence and determinants of prehypertension and hypertension among adolescents: a school based study in a rural area of Kerala, India. International Journal of Research in Medical Sciences 2015; 3(1):59. 